\title{
Effect of Micronutrient - Vegetable Special on Higher Productivity and to Improve the Socio Economic Status of Vegetable Grower of Koppal District in Karnataka, India
}

\author{
R. Jyothi", D.H. Roopashree, Raghavendra Yaligar and J. Radha \\ ICAR - Krishi Vigyan Kendra, Koppal - 583227, Karnataka, India \\ *Corresponding author
}

\section{Keywords}

Micronutrient, Vegetable special, Net returns vegetables,

Productivity and Economic status

\section{Article Info}

Accepted:

17 June 2019

Available Online:

10 July 2019

\section{A B S T R A C T}

Vegetables play important role in supply of vitamins minerals and fibers. Micronutrient demonstrations conducted by KVK, Koppal emphasized on sustainable production of vegetables with higher yield which ultimately improves the economy and better livelihood of the vegetable grower. The present demonstrations were carried out in 9 different vegetables of Solanaceous, cruciferous and cucurbitaceous-s family during 2016-17, 201718 and 2018-19 respectively. The yield related parameters like number of fruits/plant (No.), Average fruits weight (g), Average head/curd weight (Kg), crop duration (No.) etc. were recorded. In relation to this net return (Rs), extension gap ( $t / h a)$, Technology gap ( $t /$ ha) etc. were also calculated. When average number of fruits per plant was calculated it was recorded 25 fruits/plant, 17.5 fruits/plant and 27.5 fruits/plant in Tomato, Chilli and Brinjal respectively. The other yield related parameters were also recorded in increasing trend. The net returns of all the nine vegetables were recorded on higher side because of higher productivity and good market price viz., Tomato (193771 Rs/ha), Chilli (485280 Rs/ha) Cauliflower (168500 Rs/ha) etc. When we studied the productivity difference, Extension gap, technology gap and technology index, there was increased productivity was observed over farmers practice and reduces extension gap and technology gap was recoded that could be due to variation in the soil fertility, varied climatic conditions, GMP followed by the farmers and also higher rated technology adoption. The present technology was very much feasible based on the lower technology index recorded in all nine different vegetables taken up in the study.

\section{Introduction}

Managing agricultural nutrients to provide a safe food supply and secure the environment remains one of the immense challenges of the 21 st century. Crop nutrient uptake and crop yields are the principal factors that determine optimal fertilization practices. Therefore, it is very important to apply fertilizers in an efficient way to minimize loss and to improve the nutrient use efficiency (Li et al., 2009). The intensive cropping, imbalanced fertilizer usage and minimum use of micronutrients and limited application of organic manures resulted in depletion of soil fertility. Balanced fertilizer is very much essential for better 
production and productivity of crops. For any particular crop micronutrient supply is as important as application of required amount of major and secondary nutrient.

Micronutrients are essential for cell division, nitrogen and carbohydrate metabolism and water relation in plant growth (Brady, 1990). The knowledge about the mobility of micronutrient is very much important to decide the type of application which on the other hand helps in overcome the deficiency of particular micronutrient. Mobility of micronutrient in the soil has considerable influence on availability of micronutrients to plants. Foliar application of micronutrients during important phase of crop growth was successfully used for correcting the deficiency and improving the mineral status of plants as well as increasing the crop yield and quality (Kolota and Osinska, 2001). Spray application of micronutrient helps in $90 \%$ availability to the crops. The foliar application of micronutrient resulted in good plant growth yield and quality of the produce (El Tohamy et al., 2009 and Alam et al., 2010). To the best of our knowledge, previous studies on micronutrient responses were rarely conducted on important vegetable crops individually, and no one has reported micronutrient responses important vegetable crops grown particularly in KoppalTaluk of Karnataka state.

Vegetables are paramount's in supply of vitamins, minerals and fibers. Sustainable production of vegetable is very much important to improve the economy and better livelihood of the farmer. Koppal district has around 35244 ha area under horticulture crops which is around $8 \%$ of the total cultivable land i.e. 433447 ha. Out of 35244 ha 25363 ha area cultivated by vegetable crops area. With this perspective demonstrations of foliar application of Arka Vegetable special conducted in important vegetables of Solanaceous, Cruciferous and cucurbitaceous family grown in Koppal region of Karnataka. These estimates will be helpful for improving fertilizer recommendations and for achieving sustainable production in important of vegetable crops of Koppal district in Karnataka

\section{Materials and Methods}

Koppal District comes under Northern Dry Zone (Zone number 3) with $15.5^{\circ}$ latitude $32.5^{\circ}$ longitude. The present study was carried out in 33 different farmers' fields of Koppal district during 2016-17, 2017-18 and 2018-19 in important crops of 3 different vegetable family viz., Solanaceous, Cruciferous and cucurbitaceous. The important vegetable crops selected of these three major vegetable family are - Tomato, Chilliand Brinjal from Solanaceous family, Cabbage and cauliflower from Cruciferous family and Ridge gourd, Bitter gourd, cucumber and watermelon from Cucurbitaceous family. Demonstration of Solanaceous vegetables conducted in Halahalli village, Cruciferous vegetables conducted in Kataraki Village, Cucurbitaceous vegetable conducted in Gaddi village. The main aim of the demonstration was to application of Arka vegetable special (developed from Indian Institute of horticultural research, Bengaluru) as foliar application in critical phases of plant growth along with the recommended dose of NPK application. The micronutrient doses applied are as follows, for Solanaceous vegetables $5 \mathrm{~g} / \mathrm{lit}$ of water, for Cruciferous vegetable $3 \mathrm{~g} / \mathrm{lit}$ of water and for cucurbitaceous vegetable $1 \mathrm{~g} /$ lit of water. The area taken under each demonstration is 0.4 ha. The first spray was carried out 25 days after transplanting in Tomato, Brinjal, Chilli, cabbage and cauliflower, 45 days after seed sowing in ridge gourd, Bitter gourd, Cucumber and Water melon. The second and third spray was carried out in 20 days interval after $1^{\text {st }}$ spray. The demonstration was conducted with five replication in Solanaceous 
vegetable, five replication in Cruciferous and two replication in cucurbitaceous. The crop was raised with application of recommended dose of major and secondary nutrients and general cropping practices were followed with the guidance of KVK scientists in respect of package of practices. Technology gap, extension gap and technology index were calculated using following formula as suggested by Samui et al., (2000).

Demonstration yield - Farmers yield Increase yield (\%) = ----------------------- X 100 Farmers yield

Technology gap $=$ Potential yield Demonstration yield

Extension gap $=$ Demonstration yield - yield under existing practice

Potential yield - Demonstration yield Technology index $(\%)=$----------- X 100 Potential yield

\section{Results and Discussion}

\section{Yield and yield attributing parameter}

Effect of micronutrient - vegetable special on yield and yield attributing parameter are presented in Table 1.

\section{Number of fruits/plants (No.)}

Yield attributing parameters are very important to determine the ultimate yield of the particular crop. In the present demonstration Solanaceous vegetables showed increased number of fruits per plants over farmer's practices. On an average there was increase (Table 1) of 25 fruits/plant, 17.5 fruits/plant and 27.5 fruits/plant in tomato Chilli and Brinjal respectively was observed. In general vegetable growers of koppal district are not aware of application of mixture of micronutrient, critical stage of application and also type of application. In the present demonstration increased number of fruits per plant was directed to decrease in flower drop and retention of fruits at the early stage of the crop. According to Upendra et al., (2003), mineral nutrition might have increased the number of fruits per plant due to more fruit setting and retention due to availability of both secondary and micronutrient as a foliar application.

\section{Average fruit weight (g), Average curd/head weight (kg)}

Spray of micronutrient Arka vegetable special resulted in increased average fruit weight of all the important vegetables of all three families which were considered in demonstration. In Solanaceous vegetable tomato showed $82 \mathrm{~g}$ of increased average fruit weight which was followed by $50 \mathrm{~g}$ Brinjal and 13g Chilli. In Cruciferous vegetables cabbage showed $270 \mathrm{~g}$ increased average head weight which was followed by $214 \mathrm{~g}$ increased cued weight in cauliflower. In cucurbitaceous vegetables Watermelon showed $350 \mathrm{~g}$ increased average fruit weight followed by $124.5 \mathrm{~g}$ Ridge gourd, 33g in cucumber and $31.5 \mathrm{~g}$ in bitter gourd. This result could be due to better absorption of all the micronutrient and 3 Secondary nutrients by the leaves of individual plants at the time of critical stage of spray. This absorption helps in accumulation of carbohydrates in the final produce of the crop. The results of present demonstration are in accordance with the findings of Bhatt et al., (2006) and Amit et al., (2018). This average fruit increase would ultimately resulted in increased yield of the individual crop.

\section{Crop duration (days)}

Crop duration which determines the days to harvest is one of the important parameter which helps in the catch the market during 
high price. In this demonstration crop duration was recorded in cruciferous vegetables. In cabbage 14.68 days and in cauliflower 13.7 days earlier harvest was recorded. This early harvest could be due to rapid initial plant growth because of spray of micronutrient at critical stages of crop development coupled with good environmental conditions. The similar result was obtained by Patil et al., (2008).

\section{Yield (t/ha)}

There was a significant increase in the yield/ha of all the vegetables considered in the demonstration. In tomato the yield difference of 11.42 tons/ha was observed in farmers practice and the demonstration which was followed by $10.7 \mathrm{t} / \mathrm{ha}$ in Brinjal and $2.0 \mathrm{t} / \mathrm{ha}$ in
Chilli. In this Solanaceous vegetables tomato was responded well to the micronutrient mixture followed by Brinjal and Chilli. In Cucurbitaceous family $3.56 \mathrm{t} / \mathrm{ha}$ increased yield was observed in Watermelon which was followed by $3.1 \mathrm{t} / \mathrm{ha}$ in bitter gourd, $1.79 \mathrm{t} / \mathrm{ha}$ in cucumber and 1.14 t/ha. Overall watermelon and bitter gourd were responded well to the micronutrient spray. In these two families difference in the yield/ha might be possible due to increased number of fruits per plant and also increased average fruit weight. Similar results obtained from Patnaik et al., (2001) and Singh et al., (2003). In Cruciferous vegetables cabbage has given the yield difference of $2 \mathrm{t} / \mathrm{ha}$ and $1.92 \mathrm{t} / \mathrm{ha}$ in cauliflower. This increased yield could be due to increased accumulation of carbohydrates and also other minerals.

Table.1 Effect of micronutrient - vegetable special on yield and yield attributing parameter in solanaceous, cruciferous, cucurbitaceous vegetables

\begin{tabular}{|c|c|c|c|c|c|c|c|c|c|}
\hline \multicolumn{10}{|c|}{ Effect of micronutrient on yield and yield attributing parameters of Solanaceous vegetables } \\
\hline & \multicolumn{3}{|c|}{ Farmers Practice } & \multicolumn{3}{|c|}{ Demonstration } & \multicolumn{3}{|c|}{ Increase } \\
\hline Crops & $\begin{array}{l}\text { No. of } \\
\text { fruits } \\
\text { /plant }\end{array}$ & $\begin{array}{l}\text { Average } \\
\text { fruit } \\
\text { weight }(g)\end{array}$ & $\begin{array}{l}\text { Yield } \\
\text { (t/ha) }\end{array}$ & $\begin{array}{l}\text { No. of } \\
\text { fruits } \\
\text { /plant }\end{array}$ & $\begin{array}{l}\text { Average } \\
\text { fruit } \\
\text { plant }(\mathrm{g})\end{array}$ & $\begin{array}{l}\text { Yield } \\
\text { (t/ha) }\end{array}$ & $\begin{array}{l}\text { No. of } \\
\text { fruits } \\
\text { /plant }\end{array}$ & $\begin{array}{l}\text { Average } \\
\text { fruit } \\
\text { plant (g) }\end{array}$ & $\begin{array}{l}\text { Yield } \\
\text { (t/ha) }\end{array}$ \\
\hline Tomato & 40 & 343 & 44.32 & 65.0 & 425 & 55.74 & 25 & 82 & 11.42 \\
\hline Chilli & 37.5 & 30 & 5.75 & 55.0 & 43 & 7.75 & 17.5 & 13 & 2.0 \\
\hline Brinjal & 55 & 241 & 16.8 & 82.5 & 291 & 22.4 & 27.5 & 50 & 10.7 \\
\hline \multicolumn{10}{|c|}{ Micronutrient effect on yield and yield attri } \\
\hline 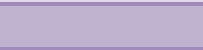 & \multicolumn{3}{|c|}{ Farmers Practice } & \multicolumn{3}{|c|}{ Demonstration } & \multicolumn{3}{|c|}{ Increase } \\
\hline Crops & $\begin{array}{l}\text { Average } \\
\text { weight of } \\
\text { Head/curd } \\
(\mathrm{kg})\end{array}$ & $\begin{array}{l}\text { Crop } \\
\text { duratio } \\
\mathrm{n}\end{array}$ & $\begin{array}{l}\text { Yield } \\
\text { (t/ha) }\end{array}$ & $\begin{array}{l}\text { Average } \\
\text { weight of } \\
\text { Head/curd } \\
(\mathrm{kg})\end{array}$ & $\begin{array}{l}\text { Crop } \\
\text { duration }\end{array}$ & $\begin{array}{l}\text { Yield } \\
\text { (t/ha) }\end{array}$ & $\begin{array}{l}\text { Average } \\
\text { weight of } \\
\text { Head/curd } \\
(\mathrm{kg})\end{array}$ & $\begin{array}{l}\text { Crop } \\
\text { duration }\end{array}$ & $\begin{array}{l}\text { Yield } \\
\text { (t/ha) }\end{array}$ \\
\hline Cabbage & 1.74 & 85.00 & 15.00 & 2.01 & 70.32 & 17 & 0.270 & 14.68 & 2.00 \\
\hline Cauliflower & 0.760 & 83.20 & 11.58 & 0.974 & 69.5 & 13.5 & 0.214 & 13.7 & 1.92 \\
\hline \multicolumn{10}{|c|}{ Micronutrient effect on Yield and yield attributing parameters of cucurbitaceous vegetables } \\
\hline & \multicolumn{3}{|c|}{ Farmers Practice } & \multicolumn{3}{|c|}{ Demonstration } & \multicolumn{3}{|c|}{ Increase } \\
\hline Crops & \multicolumn{2}{|c|}{$\begin{array}{l}\text { Average } \\
\text { weight of } \\
\text { fruits }(\mathrm{g})\end{array}$} & Yield (t/ha) & $\begin{array}{l}\text { Average } \\
\text { weight of } \\
\text { fruits (g) }\end{array}$ & \multicolumn{2}{|c|}{ Yield (t/ha) } & $\begin{array}{l}\text { Average } \\
\text { weight of } \\
\text { fruits }(g)\end{array}$ & \multicolumn{2}{|c|}{ Yield (t/ha) } \\
\hline Ridge gourd & 501.5 & & 4.96 & 626.0 & \multicolumn{2}{|l|}{6.10} & 124.5 & \multicolumn{2}{|l|}{1.14} \\
\hline Bitter gourd & \multicolumn{3}{|l|}{270.0} & 301.5 & \multicolumn{2}{|l|}{10.63} & 31.5 & \multicolumn{2}{|l|}{1.1} \\
\hline Cucumber & \multicolumn{3}{|l|}{205.0} & 238.0 & \multicolumn{2}{|l|}{13.51} & 33.0 & \multicolumn{2}{|l|}{1.79} \\
\hline Watermelon & \multicolumn{3}{|l|}{$3.9(\mathrm{~kg})$} & $4.25(\mathrm{~kg})$ & 43.29 & & 350.0 & 3.56 & \\
\hline
\end{tabular}


Table. 2 Economic benefit from micronutrient - vegetable special spray in solanaceous, cruciferous, cucurbitaceous vegetables

\begin{tabular}{|l|l|l|l|l|l|l|}
\hline Crops & \multicolumn{3}{|c|}{ Farmers Practice } & \multicolumn{3}{c|}{ Demonstration } \\
\hline Tomato & $\begin{array}{c}\text { Gross } \\
\text { cost } \\
\text { (Rs.) }\end{array}$ & $\begin{array}{c}\text { Gross } \\
\text { Returns(Rs.) }\end{array}$ & $\begin{array}{c}\text { Net } \\
\text { returns } \\
\text { (Rs.) }\end{array}$ & $\begin{array}{c}\text { Gross } \\
\text { cost(Rs.) }\end{array}$ & $\begin{array}{c}\text { Gross } \\
\text { Returns(Rs.) }\end{array}$ & $\begin{array}{c}\text { Net } \\
\text { returns(Rs.) }\end{array}$ \\
\hline Chilli & 61800 & 218500 & 136700 & 84929 & 278700 & 193771 \\
\hline Brinjal & 102500 & 484300 & 419800 & 71980 & 557260 & 485280 \\
\hline Cabbage & 40400 & 241200 & 139200 & 109600 & 333200 & 223600 \\
\hline Cauliflower & 48000 & 183000 & 39900 & 43500 & 105000 & 61500 \\
\hline Ridgegourd & 44350 & 74325 & 295000 & 51500 & 220000 & 168500 \\
\hline Bittergourd & 63897 & 104830 & 40933 & 66500 & 84975 & 36175 \\
\hline Cucumber & 52975 & 122250 & 69275 & 55850 & 127560 & 61045 \\
\hline Watermelon & 58815 & 278075 & 219260 & 60800 & 335332 & 274532 \\
\hline
\end{tabular}

Table.3 Effect of micronutrient- vegetable spray on percent increase of productivity and extension gap, technology gap and technology index

\begin{tabular}{|l|l|l|l|l|c|c|}
\hline Crops & $\begin{array}{l}\text { Average } \\
\text { yield in } \\
\text { FLD } \\
\text { (t/ha) }\end{array}$ & $\begin{array}{l}\text { Yield in } \\
\text { Farmers } \\
\text { practice (t/ha) }\end{array}$ & $\begin{array}{l}\text { Increase } \\
\text { over } \\
\text { Farmers } \\
\text { Practice }\end{array}$ & $\begin{array}{l}\text { Extension } \\
\text { gap (t/ha) }\end{array}$ & $\begin{array}{l}\text { Technology } \\
\text { gap (t/ha) }\end{array}$ & $\begin{array}{l}\text { Technology } \\
\text { index (\%) }\end{array}$ \\
\hline Tomato & 55.74 & 44.32 & 25.76 & 11.42 & 19.26 & 25.68 \\
\hline Brinjal & 22.40 & 16.8 & 33.33 & 2.00 & 7.60 & 25.33 \\
\hline Chilli & 7.75 & 5.75 & 34.78 & 10.70 & 2.25 & 22.50 \\
\hline Cabbage & 17.00 & 15.00 & 13.33 & 2.00 & 3.00 & 15.00 \\
\hline Cauliflower & 13.50 & 11.58 & 16.58 & 1.92 & 1.500 & 10.00 \\
\hline Ridge gourd & 6.10 & 4.96 & 22.98 & 1.14 & 1.900 & 23.75 \\
\hline Bitter gourd & 10.63 & 9.53 & 11.54 & 1.10 & 1.37 & 11.41 \\
\hline Cucumber & 13.51 & 11.72 & 15.27 & 1.79 & 1.49 & 9.93 \\
\hline Watermelon & 43.29 & 39.73 & 8.96 & 3.56 & 1.71 & 3.80 \\
\hline
\end{tabular}

Response of the micronutrient to the net returns

Data related to gross income and net income are presented in Table 2 .

\section{Net returns/ha (Rs)}

Net returns of any crop are very much important to improve the socio economic status of the farmers. The main aim of the any demonstration conducted through Krishi Vigyan Kendra is to improve the overall production, enhance the productivity and improve the quality of the produce. In these demonstrations the Micronutrient spray technology demonstrated resulted in getting the higher returns to the vegetable grower. With the increased productivity per hectare area was observed which resulted in increased net returns in every crop taken into consideration under demonstration. In tomato 
there was 57071 Rs per hectare difference in the net returns was observed over farmers practice. In the similar way $65480 \mathrm{Rs}$ in Chilli, 84400 Rs in Brinjal, 21600 Rs in Cabbage, 33500Rs in Cauliflower, 6200 Rs in Ridge gourd, 20112 Rs in Bitter gourd, 26015Rs in Cucumber, 55272 Rs in Watermelon was obtained to the vegetable grower from micronutrient spray. The more price to the produce was obtained basically from increased yield of the individual crop under demonstration which was supported by the improved quality of the produce. According to the farmer's opinion spray of micronutrient helped in improvement of quality of the vegetable through attractive appearance. This quality improvement helped in higher market price nearly 3-7 Rs per $\mathrm{kg}$ of the produce than the produce from the farmers practice.

Effect of micronutrient spray on percent increase of productivity and Extension gap, technology gap and technology index are present in Table 3.

Productivity increase (\%), extension gap (t/ha) and technology gap (t/ha)

Micronutrient spray resulted in more increase of productivity in Chilli, Brinjal, tomato and ridge gourd i.e. more than $20 \%$. More than $10 \%$ productivity increase was observed in cauliflower, cabbage, bitter gourd and cucumber. Crop watermelon repose was observed less than $10 \%$. In relation to increased productivity reduced extension gap and technology gap was observed. In tomato extension gap and technology gap was 11.42 t/ha and $19.26 \mathrm{t} /$ ha respectively. Similar kind of result was obtained by Savita et al., (2016) in Okra. On the other hand it was less than $10 \mathrm{t} / \mathrm{ha}$ in rest of the other vegetable which considered under the demonstration. The technological gap observed may be attributed to variability of soil fertility, climatic condition, management practices, also adoption by the particular farmer and extent of area covered by the particular crop. The extension gap emphasized the need to educate the farmers through various means for the adaptation of this particular micronutrient management in major vegetable crops of Koppal district.

\section{Technology index $(\%)$}

During the present demonstration more decreased technology index was observed in Cabbage (15\%), Cauliflower (10\%), Bitter gourd (11.41), Cucumber (9.93\%) and Watermelon $(3.80 \%)$ than the other vegetables under demonstration viz., Tomato (25.68\%), Brinjal (25.33\%), Chilli (22.50\%) and Ridge gourd $(23.75 \%)$. The technology index always shows the feasibility of the particular technology at the farmer field. Lower the value of the technology index indicates the more feasibility of the technology.

\section{References}

Amit Dixit., Sharma, D., Tinku, K. and Pappu, L. Bairwa. 2018. Effect of foliar application of some macro and micronutrients on growth and yield of tomato (Solanum lycopersicum L.) cv. Arka Rakshak. Int. J.Curr.Microbiol.App. Sci. 6, 197-203.

Bhatt, L., Srivastava, B.K. and Bhatt Singh, M.P. 2004. Studies on effect of application of micronutrients on nutrient uptake in tomato. Prog.Hort, 36(2), 331-334.

Brady, N.C. 1990. The nature and Properties of soils. $10^{\text {th }}$ edition, A.K. Ghosh. Printing Hall of India Pvt. Ltd., New Delhi. Pp. 383.

El-Tohamy, W.A., El-Abagy, H. M. and Abou-Husein, S. D. 2009. Essential oil, growth and yield of onion (Allium cepa 
L.) in response to application of some micronutrient, Aus J Basic App Sci., 3, 201-205.

Kolota, E. and Osinska, M. 2001. Efficiency of foliar nutrition of field vegetables grown at different nitrogen rates. ActaHortitultute. 563, 87-91.

Li, X., Lu, J., Wu, L. and Chen, F. 2009. The difference of potassium dynamics between yellowish red soil and yellow cinnamon soil under rapeseed (Brassica napus L.)-rice (Oryza sativa $\mathrm{L}$.) rotation. Plant Soil 320, 141-151, doi:10.1007/s11104-008-9879-7.

Patil, B.C., Hosamani, R.M., Ajjappalavara, P.S., Naik, B.H., Smitha, R.P. and Ukkund, K.C. 2008. Effect of foliar application of micronutrients on growth and yield components of Tomato (Lycopersicon esculentum Mill).
Karnataka J. Argic. Sci., 21(3), 528430.

Patnaik, M.C., Bhupal, R. G. and Reddy, I.P, 2001. Response of tomato (Lycopersicon esculentum to zinc and Iron. Veg. Sci., 28: 78-79.

Samui S K, Mitra S, Roy D K, Mandal A K and Saha D. 2000. Evaluation of front line demonstration on groundnut. $J$ of the IndSoci Costal Agri Res. 18(2), 180183.

Savita, R., Angad, S.K., Verma, S.K. and Jain, V. 2016.Impact of front line demonstration on Okra (Abelmoschus esculentus (L.). J KrishiVigyan, 5(1): 74-76.

Upendra, M., Dris, S.R. and Singh B. 2003. Mineral nutrition of tomato. $J$ of Food, Agri and Envit. 1(2), 176-183.

\section{How to cite this article:}

Jyothi, R., D.H. Roopashree, Raghavendra Yaligar and Radha, J. 2019. Effect of Micronutrient - Vegetable Special on Higher Productivity and to Improve the Socio Economic Status of Vegetable Grower of Koppal District in Karnataka, India. Int.J.Curr.Microbiol.App.Sci. 8(07): 2343-2349. doi: https://doi.org/10.20546/ijcmas.2019.807.287 